\title{
Optimal Use of Agricultural Land and Water Resources through Reconfiguring Crop Plan for different Agro-Climatic Zones of Bihar (India)
}

\author{
Nasim Ahmad*, D.K. Sinha and K.M. Singh \\ Department of Agricultural Economics, Dr. Rajendra Prasad Central Agricultural University, \\ Pusa, Samastipur (Bihar)-841 125 \\ *Corresponding author
}

\begin{tabular}{|l|}
\hline Key w o r d s \\
Optimization, \\
Market price, \\
Economic price, \\
Natural resource \\
valuation prices \\
\hline Article Info \\
\hline Accepted: \\
26 December 2017 \\
Available Online: \\
10 January 2018 \\
\hline \hline
\end{tabular}

\section{A B S T R A C T}

An optimization model has been formulated for optimal use of land and water resources and maximizing benefits using linear programming to reconfigure the crop model prevailing in the agro-climatic zones of Bihar. The study is based on data of "Comprehensive scheme to study the cost of cultivation of principal crops in Bihar" for the block period 2008-09 to 2010-11. The performance of different crops was assessed by computing net returns under three alternative scenarios (i) Market prices (MP) (ii) Economic prices net of subsidies (EP); and (iii) Net income based on natural resource valuation technique (NRV). Optimum crop model for agro-climatic zones of Bihar revealed that with existing ground water use at $4.50 \mathrm{BCM}$ in zone-I, the net gain to the cultivator was positive at all the three prices i.e. 9.18 at MP, 7.70 at EP and 2.98 at NRV hundred crores, respectively. In zone-II, the model was applied in two different groundwater use scenarios one at 2.12 BCM existing GW use and another at $2.65 \mathrm{BCM}$. In the first condition, the net gains were estimated to $3.50,3.12$ and 0.61 hundred crores at all alternative business prices and in other situation farmer's gain was calculated to be positive i.e. 4.36 hundred crores on market price, whereas for rest two other prices, the gains were -0.71 and -2.19 hundred crores at EP and NRV prices. The model for zone-III depicted positive change in farmers' revenue only in case of market price at $3.70 \mathrm{BCM}$ groundwater use but gain to the society at two prices EP and NRV were calculated 9.03 and 7.13 hundred crores, respectively and the final net gain to cultivators were estimated 9.15, 6.99 and 2.64 hundred crores at MP, EP and NRV, respectively under $4.63 \mathrm{BCM}$ GW use scenario.

\section{Introduction}

Water scarcity has emerged as a common issue in many areas of the world due to ever growing population and leaping economic development. Soaring population has led to increased demand for food and farmland expansion, which are hard to be supported by physically limited natural resources. This has resulted into the emergence of various issues for their efficient uses, management and sustainability. Only 2.7 percent of the global water is available as fresh water, out of which only 30 percent can be used for meeting 
demand for human and livestock. The demand for land and water is expected to increase manifold owing to increasing population, rising demand for food, urbanization and industrialization. This situation will prevail in almost all parts of the world, more pronounced in those economies where agriculture occupies a dominant position.

Bihar, with its bountiful natural resources of fertile soil, abundant ground water (Table 1), varied climate and rich cultural and historical heritage is one of the most fascinating states of India. The farmers are intelligent and hard working. Therefore, agriculture has been described as the core competence of Bihar.

Agriculture is considered as backbone of the economy of Bihar. The percentage of population employed in agricultural production system in Bihar is estimated 81 per cent, which is much higher than the national average. Nearly 17 percent of GDP of the state during 2016-17 has been from agricultural sector including forestry and fisheries.

Bihar with geographical area of about 94.2 thousand square kilometers is divided by river Ganga into two parts, the north Bihar with an area of 53.3 thousand square kilometers and the south Bihar having an area of 40.9 thousand square kilometers. Based on soil characterization, rainfall, temperature and terrain, the state is categorized into four comprehensive agro-climatic zones.

\section{Zone-I (North-West Alluvial Plains)}

The northern plains include Saran, Siwan, Gopalganj, East Champaran, West Champaran, Sheohar, Sitamarhi, Madhubani, Darbhanga, Muzaffarpur, Vaishali, Samastipur and Begusarai districts. The sub-zone is at foot of Himalaya and receives $1275 \mathrm{~mm}$ rainfall. The climate is dry to moist sub-humid and soil type is heavy textured sandy loam to clayey, medium acidic. Over 70 per cent of land in this sub zone is arable and about $42 \%$ of this is irrigated.

\section{Zone-II (North-East Alluvial Plains)}

Supaul, Khagaria, Saharsa, Madhepura, Purnea, Katihar, Kisangunj, Araria, Naugachhia districts of Bihar constitute this sub-zone. Being at the end of mid-Gangetic valley, drainage and management of floods and seasonal rushes are problem in the region. A little over 60 per cent of land is cultivated and $44 \%$ of this is irrigated. The region receives $1224 \mathrm{~mm}$ of rainfall and the climate is similar to other sub-zones in Bihar plain, dry to moist sub-humid. Cropping intensity in this zone is high relative to the other sub-zone in Bihar; however, the land productivity is low.

\section{Zone-III (South Alluvial Plains)}

The south Bihar plains cover Patna, Nalanda, Bhojpur, Rohtas, Bhabhua, Gaya, Jahanabad, Arwal, Nawada, Aurangabad district in zoneIII-B and Sheikhpura, Lakhisarai, Jamui, Banka, Munger and Bhagalpur districts in zone-III-A. The region is well irrigated over $75 \%$ of the cropped area, covered by irrigation, which is mostly through a network of canals. However, the proportion of net sown area is relatively low at $54 \%$ and the cropping intensity is also relatively low at 121 $\%$, about $13 \%$ of the land is under forest cover.

To meet the growing need of nutritional security to an increasing population, it is necessary to bring more area under cultivation or increase production per unit area of available and water resources (Dahiphale et al. 2015). In states like Bihar, there is a growing need to increase the income and employment of the farmers, through optimal crop planning (Singh, et al. 1990). Overall development of 
the state depends on agriculture as it is the backbone of the state economy (Singh et al. 2015). Agriculture depends on land and water. Due to urbanization and a reluctance to disturb environments, there is difficult task to bring the additional land under agricultural uses.Net sown area is shrinking due to urbanization and non-agricultural uses of the land (Sinha at al., 2016). Hence, it is important to optimize the available land and water resources to achieve maximum production (Rani and Rao, 2012). This requires proper planning and management process of land and water resources and appropriate uses ofavailable technologies.

Here effort is being made to maximize the income of the cultivators from raising the crops, considering the important constraints viz., land constraints and water constraints. Land constraint uses allocation of the minimum and maximum area for each crop grown in the state, assuming the considerable area under major staple food crops (paddy, wheat and maize etc.) from the food security point of view in the state (Singh et al.1990) However, it is contemplated that what methods/ devices should be used to draft a desired level of groundwater at minimum cost in order to maximize the cultivator's income. The diesel energy used for irrigating the crops is much costlier than electricity and releases $\mathrm{CO}_{2}$ and, in turn, also helps to push up surroundings environmental pollution level.

The utilization of cheap source of energy such as electricity/solar will certainly raise the income level of farming community in particular and on the other hand, the national exchequer also, in general. An attempt has been made in this paper, to revise the existing zonal crop plans using linear programming considering land and water as constraints in each of the three agro-climatic zones of the state.

\section{Materials and Methods}

The present study is based on farm-wise data collected under Comprehensive Cost of Cultivation Scheme (CCCS), Ministry of Agriculture and Farmers Welfare, Government of India, running in Bihar. Secondary data for area of different crops were collected from various issues of Economic Survey of Bihar and Bihar through Figures. Data regarding groundwater use was obtained from the Annual Report of Central Groundwater Board, Patna.

\section{Cost-return analysis}

The performance of different crops was assessed by computing net returns under alternative scenarios. The alternative scenarios are (i) Market prices (ii) Economic prices net of subsidies; and (iii) Net income based on natural resource valuation technique (NRV) (Raju et al. 2015). For cost-return analysis of various crops grown in Bihar, the primary data concerning cost and returns for 450 sample farmers were obtained from Comprehensive Cost of Cultivation Scheme for the block year, 2008-11 for the state of Bihar.

Besides this, input-output data were also generated through survey of few crops like cabbage, cauliflower, tomato, chilli, sunflower, linseed, barely, ragi, kulthi (horsegram) and onion for the year 2014-15 and further cost and returns for the above crops were deflated to 2008-11 price level.

\section{Net return at market prices $\left(\mathbf{N R}_{\mathrm{MP}}\right)$}

Net return at market price is defined as the gross return (value of main product and by product) less variable costs $\left(\right.$ Cost $\mathrm{A}_{1}+$ imputed value of family labour) at market price actually paid and received by the farmer or imputed in some cases. 
$N R_{M P}=G R-V C$

Where, $\mathbf{N R}_{\mathbf{M P}}$-Net return at market prices; GR- Gross Returns; VC-Variable Cost (Cost $\mathrm{A}_{1}$ )

\section{Net returns at economic prices $\left(\mathrm{NR}_{\mathrm{EP}}\right)$}

Net return at economic price was defined as the difference between net return or income at market prices and subsidies on inputs like fertilizers, irrigation and seed used in crop production.

\section{i.e. $\quad N R_{E P}=N R_{M P}-$ subsidy}

Thus, subsidy component has been internalized into the model, by covering three aspects viz., fertilizers subsidy, irrigation subsidy and seed subsidy.

Fertilizer subsidy included subsidy on nitrogen, phosphorous and potassium. Fertilizer subsidy per kilogram was estimated at Rs. 19.347 per $\mathrm{kg}$ of N; Rs. 42.563 per $\mathrm{kg}$ of P\& K for TE-2010-11. Quantity of fertilizers application for different crops under CCC Scheme for TE-2010-11 was used for calculation of subsidy on fertilizers.

\section{Net returns based on natural resource valuation $\left(\mathbf{N R}_{\mathrm{NRV}}\right)$}

Net return based on Natural Resource Valuation (NRV) technique has taken care of nitrogen fixation by legume crops and Green House Gas (GHG) emission from crop production. Thus, $\mathrm{NR}_{\mathrm{NRV}}$ is computed by adding value of nitrogen fixation by legume crops at economic price of nitrogen and deducting the imputed value of GHG emission cost to the atmosphere.

i.e.

$N R_{N R V}=N R_{E P}+($ value of $N-$

Cost of $\mathrm{GHG}$ )
Legumes are environment-friendly crops and are different from other food plants because of property of synthesizing atmospheric nitrogen into plant nutrients. As such, the economic valuation has been done by taking into account the positive externality of legume crops by biological nitrogen fixation and negative externality of GHG emission.

The data on contribution of pulses by biological nitrogen fixation and emission from different crops were collected from various published scientific literatures, (Peoples et al.,1995, IIPR, 2003, IARI, 2014). The value of $\mathrm{GHG}$ emissions in terms of $\mathrm{CO}_{2} \mathrm{Kg}$ equivalent was taken at the rate of 10 US dollar per tonne. Biological nitrogen fixation for various crops was calculated by taking the average value of nitrogen fixed by various legumes and then multiplied with the economic price of nitrogen prevailed in the TE-2010-11.

\section{Optimum crop model}

The Mathematical Programming was used for developing optimum crop or land use planning. It is an easy and flexible method for assessing different ways to use limited resources under variable objective and constraints. GAMES software was used to analyze the data. The present study makes an attempt to develop different crop planning strategies by using Linear Programming $(L P)$.

\section{Mathematical specifications of the model}

Mathematical model specification for Bihar are given as under

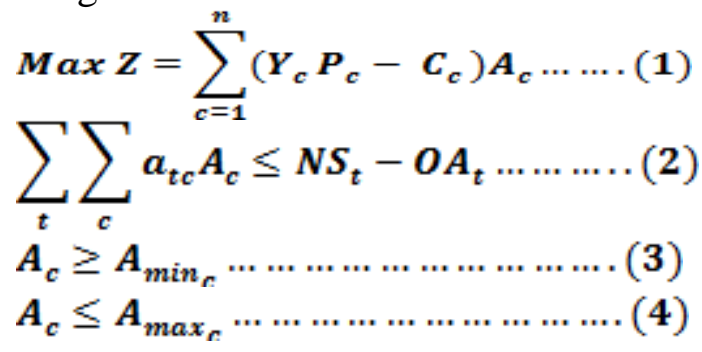




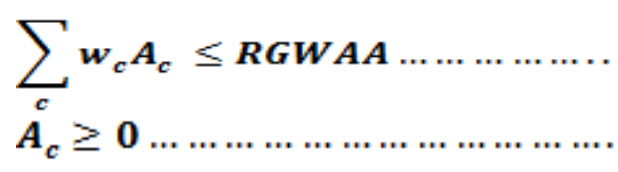

Objective function: Maximization of net income (equation 1)

$\operatorname{Max} Z=\sum_{c=1}^{n}\left(Y_{c} P_{c}-C_{c}\right) A_{c} \ldots \ldots$

Let $\mathbf{Y}_{\mathbf{c}}$ denotes yield of crop $\mathbf{c}$ in one hectare of land, $\mathbf{P}_{\mathbf{c}}$ the price received for the output from crop $\mathbf{c}, \mathbf{C}_{\mathbf{c}}$ refers to the cost incurred to cultivate crop $\mathbf{c}$ in one hectare of land and $\mathbf{A}_{\mathbf{c}}$ is the area under cultivation of crop $\mathbf{c}$ then RHS of the equation 1 represents sum of net revenue obtained from all the crops considered for optimum model development. The objective is to maximize the net revenue $(\mathbf{Z})$ based on the optimum crop plan.

\section{Land constraint}

Optimal use of land for each month is required, this can be achieved by having separate constraint equation (Equation 2 is a compact form of 12 equations months for Jan, Feb........ Dec). This helps to have separate sown area for each month and ensures that total cultivated area under selected crops in each month should be less than net sown area $\left(\mathbf{N S}_{\mathbf{t}}\right)$ minus area under orchard $\left(\mathbf{O A}_{\mathbf{t}}\right)$ crops. Further, crop calendar is required for the analysis. Thus $\mathbf{a}_{\mathbf{t c}}$ in equation 2 refers to the coefficients of crop calendar matrix for $\mathbf{t}^{\text {th }}$ month and $\mathbf{c}^{\text {th }}$ crop

\section{Optimization of land constraint (equation 2)}

$\sum_{t} \sum_{c} \alpha_{t c} A_{c} \leq N S_{t}-O A_{t}$

Minimum and maximum constraints (Equation 3-4)

Crop planning model using LP primarily captures the supply side behavior especially area response based on net returns and resource constraints ignoring the demand aspect. Such models tend to overestimate or underestimate the area allocations for some crops. As a consequence, a single crop may cover infeasible larger area (Overestimation) or null or negligible area (underestimation).

In some modeling solutions, some major crops may drastically lose their relevance and the corresponding area allocation may become negligible. Then, even though estimates are robust and mathematically proven, such allocations may not be desirable and practically possible from the food and livelihood security point of view of the farming community as appropriate changes in policy framework is required for the optimum sustainable crop model. Similarly, area for some minor crop may be overestimated ignoring the demand. To overcome such situations assigning values to minimum and maximum area is essential in the model. To eliminate such practically undesirable solutions, concept of $\min , \max$ constraint is adopted in the model.

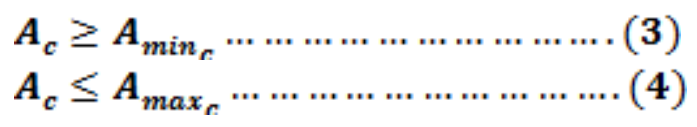

Existing land area allocations under different crops are useful to make comparison with optimal crop plan model. The lands under different crops were collected from statistical abstract of the state. Further, this data is useful for defining the minimum and maximum area allocation limits for selected crops. Existing area under different crops are the average of three years data under the crop. Min and max area have been decided on the basis of expert advice.

\section{Groundwater constraint}

Water is scarce natural resource. The groundwater usage should be less than or equal to replenishable groundwater available for agriculture (RGWAA) for making the agriculture sustainable. Data regarding RGWAA is published by Central Ground Water Board. This can also be estimated by deducting water consumed by industries and other non-farm 
activities from total replenishable groundwater. Ground water constraint to be used in LP model is prescribed as under:

$\sum_{c} w_{c} A_{c} \leq R G W A A$

$\boldsymbol{A}_{c} \geq 0$

Where, $\mathbf{w}_{\mathbf{c}}$ is actual water drafted for a crop $\mathbf{c}$ in the recent year based on cost of cultivation data. $\mathbf{A}_{\mathbf{c}}$ indicates the area allocation for a crop c. Equation-6 is the usual non-negativity constraint in the model.

Regarding groundwater constraint, two situations of groundwater uses are considered such as income maximization at existing groundwater use and secondly, when the groundwater use is increased by $25 \%$ more than existing level.

\section{Results and Discussion}

Optimal crop plans for different agroclimatic zones of Bihar

\section{Optimal crop model for Agro-climatic zone-I}

The optimal crop model for zone-I is depicted in Table 2 and Table 3. Perusal of the Table 2 indicated that in case of existing groundwater at 4.50 BCM, it was revealed that almost all crops i.e. paddy, wheat, maize, ragi, barely, redgram, lentil, khesari, moong, urad, pea, rapeseed \& mustard, linseed, potato, cabbage, brinjal, cauliflower, okra, sugarcane and chilli as included in the model showed positive direction of changes in optimal area allocation in all the three prices scenario i.e. MP, EP and NRV in this zone.

Further, it was observed that at the level of existing GW uses the optimal GCA was found to be increased i.e. 3395.00 thousand hectares from existing GCA being only 3170.00 thousand hectares for zone-I.

Perusal of the Table 3 explained the fact that for existing GW use at $4.50 \mathrm{BCM}$, the optimal net returns could be assessed 60.41, 47.64 and 45.24 hundred crores at three prices MP, EP and NRV. Finally the net gain to the cultivator was obtained positive at all the three prices i.e 9.18 hundred crores at MP, 7.70 hundred crores at EP and 2.98 hundred crores at NRV prices. Hence, it is opined that even at existing GW use, the net income/return of the cultivators may be optimized by growing the crops as indicated in the optimal model in zone-I.

\section{Optimal crop model for Agro-climatic zone-II}

Agro-climatic zone-II is vulnerable to floods and also known as the place for sorrow of Kosi River. The optimal crop model for this zone was also estimated using two different groundwater use scenarios i.e one at 2.12 $\mathrm{BCM}$ existing $\mathrm{GW}$ use and another groundwater use increased to $2.65 \mathrm{BCM}$ (increased by $25 \%$ of existing GW use) and are presented in Table 4, Table 5 and Table 6.

Table.1 Groundwater resources availability and utilization in Bihar

\begin{tabular}{|l|c|c|c|}
\hline \multicolumn{1}{|c|}{ State/Zone } & $\begin{array}{c}\text { Groundwater } \\
\text { availability } \\
\text { (BCM) }\end{array}$ & $\begin{array}{c}\text { Annual Groundwater } \\
\text { draft for irrigation } \\
\text { (BCM) }\end{array}$ & $\begin{array}{c}\text { Net Groundwater } \\
\text { availability for future } \\
\text { irrigation } \\
\text { (BCM) }\end{array}$ \\
\hline Zone-I & 10.83 & 4.44 & 5.16 \\
\hline Zone-II & 5.79 & 2.12 & 3.14 \\
\hline Zone-III & 9.65 & 3.70 & 5.80 \\
\hline Bihar & 26.27 & 10.26 & 14.10 \\
\hline
\end{tabular}

Source: GWB, Patna 2011 
Table.2 Optimum crop model for Agro-climatic zone-I in Bihar for existing groundwater at 4.50 BCM

\begin{tabular}{|l|}
\hline Crops \\
\\
\hline Paddy \\
\hline Wheat \\
\hline Maize (kharif) \\
\hline Maize (rabi) \\
\hline Ragi \\
\hline Barely \\
\hline Arhar (RedGram) \\
\hline Lentil \\
\hline Khesari (Lathyrus) \\
\hline Moong (GreenGram) \\
\hline Urad(BlackGram) \\
\hline Pea \\
\hline Rapeseed \& mustard \\
\hline Linseed \\
\hline Potato \\
\hline Cabbage \\
\hline Brinjal \\
\hline Cauliflower \\
\hline Okra (Bhindi) \\
\hline Sugarcane \\
\hline Chilli \\
\hline GCA \\
\hline Profit (00 crores) \\
\hline
\end{tabular}

\begin{tabular}{|l|l|l|l|l|}
\hline $\begin{array}{l}\text { Existing area } \\
(\mathbf{0 0 0} \text { ha) }\end{array}$ & $\begin{array}{l}\text { Optimum area (000 ha) } \\
\text { Market } \\
\text { price } \\
\text { (MP) }\end{array}$ & $\begin{array}{l}\text { Economic } \\
\text { price } \\
\text { (EP) }\end{array}$ & $\begin{array}{l}\text { Natural resource } \\
\text { valuation (NRV) }\end{array}$ & $\begin{array}{l}\text { Direction } \\
\text { of change }\end{array}$ \\
\hline 1320.33 & 1400.00 & 1400.00 & 1400.00 & +++ \\
\hline 954.33 & 1025.00 & 1025.00 & 1025.00 & +++ \\
\hline 83.45 & 100.00 & 100.00 & 100.00 & +++ \\
\hline 120.39 & 150.00 & 150.00 & 150.00 & +++ \\
\hline 4.78 & 6.00 & 6.00 & 6.00 & +++ \\
\hline 2.00 & 5.00 & 5.00 & 5.00 & +++ \\
\hline 14.67 & 20.00 & 20.00 & 20.00 & +++ \\
\hline 45.33 & 55.00 & 55.00 & 55.00 & +++ \\
\hline 5.00 & 5.00 & 5.00 & 5.00 & +++ \\
\hline 82.22 & 100.00 & 100.00 & 100.00 & +++ \\
\hline 18.66 & 25.00 & 25.00 & 25.00 & +++ \\
\hline 7.35 & 11.50 & 11.50 & 11.50 & +++ \\
\hline 42.25 & 60.00 & 60.00 & 60.00 & +++ \\
\hline 11.64 & 15.00 & 15.00 & 15.00 & +++ \\
\hline 71.66 & 100.00 & 100.00 & 100.00 & +++ \\
\hline 17.70 & 20.00 & 20.00 & 20.00 & +++ \\
\hline 25.31 & 30.00 & 30.00 & 30.00 & +++ \\
\hline 28.32 & 35.00 & 35.00 & 35.00 & +++ \\
\hline 26.66 & 30.00 & 30.00 & 30.00 & +++ \\
\hline 147.46 & 200.00 & 200.00 & 200.00 & +++ \\
\hline 2.00 & 2.50 & 2.50 & 2.50 & +++ \\
\hline 3170.00 & 3395.00 & 3395.00 & 3395.00 & +++ \\
\hline & & & 45.24 & \\
\hline & & & & ++ \\
\hline
\end{tabular}

Table.3 Gain due to optimal crop model over existing scenario in Agro-climatic zone-I of Bihar

\begin{tabular}{|c|c|c|c|c|c|c|}
\hline Optimal scenario & $\begin{array}{l}\text { Change } \\
\text { in GCA \% }\end{array}$ & $\begin{array}{l}\text { Existing } \\
\text { revenue } \\
\text { (00 crores) }\end{array}$ & $\begin{array}{l}\text { Optimal net } \\
\text { returns } \\
\text { ( } 00 \text { crores) }\end{array}$ & $\begin{array}{l}\text { Change in farmer's } \\
\text { revenue } \\
\text { ( } 00 \text { crores) } \\
\text { (Optimal-Existing } \\
\text { MP) }\end{array}$ & $\begin{array}{l}\text { Gain to } \\
\text { society } \\
(00 \\
\text { crores) }\end{array}$ & $\begin{array}{l}\text { Net gain } \\
\text { (00 crores) }\end{array}$ \\
\hline \multicolumn{7}{|c|}{ Groundwater use at existing scenario (4.45 BCM) } \\
\hline Market price & 7.10 & 51.23 & 60.41 & 9.18 & 0 & 9.18 \\
\hline Economic price & 7.10 & 39.94 & 47.64 & -3.59 & 11.29 & 7.70 \\
\hline NRV & 7.10 & 37.63 & 45.24 & -5.99 & 8.97 & 2.98 \\
\hline
\end{tabular}


Table.4 Optimum crop model for Agro-climatic zone-II of Bihar at existing GW use (2.12 BCM)

\begin{tabular}{|l|}
\hline Crops \\
\hline Paddy \\
\hline Wheat \\
\hline Maize (rabi) \\
\hline Lentil \\
\hline Rapeseed \& mustard \\
\hline Sunflower \\
\hline Potato \\
\hline Cabbage \\
\hline Brinjal \\
\hline Cauliflower \\
\hline Okra (bhindi) \\
\hline Jute \\
\hline Chilli \\
\hline GCA \\
\hline Profit (00 crores) \\
\hline
\end{tabular}

\begin{tabular}{|l|l|l|l|l|}
\hline $\begin{array}{l}\text { Existing } \\
\text { area (000 } \\
\text { ha) }\end{array}$ & $\begin{array}{l}\text { Optimum area (000 ha) } \\
\text { price (MP) }\end{array}$ & $\begin{array}{l}\text { Economic } \\
\text { price (EP) }\end{array}$ & $\begin{array}{l}\text { Natural resource } \\
\text { valuation (NRV) }\end{array}$ & $\begin{array}{l}\text { Direction of } \\
\text { change }\end{array}$ \\
\hline 681.67 & 584.90 & 584.90 & 584.90 & --- \\
\hline 312.00 & 350.00 & 350.00 & 350.00 & +++ \\
\hline 174.12 & 200.00 & 200.00 & 200.00 & +++ \\
\hline 11.00 & 15.00 & 15.00 & 15.00 & +++ \\
\hline 19.70 & 20.00 & 20.00 & 20.00 & +++ \\
\hline 18.97 & 25.00 & 25.00 & 25.00 & +++ \\
\hline 34.28 & 40.00 & 40.00 & 40.00 & +++ \\
\hline 8.79 & 12.00 & 12.00 & 12.00 & +++ \\
\hline 12.57 & 15.00 & 15.00 & 15.00 & +++ \\
\hline 14.06 & 20.00 & 20.00 & 20.00 & +++ \\
\hline 13.24 & 20.00 & 20.00 & 20.00 & +++ \\
\hline 123.96 & 150.00 & 150.00 & 150.00 & +++ \\
\hline 0.68 & 1.00 & 1.00 & 1.00 & +++ \\
\hline 1425.04 & 1452.90 & 1452.90 & 1452.90 & +++ \\
\hline & & & 20.87 & \\
\hline & & & & + \\
\hline
\end{tabular}

Table.5 Optimum crop model for Agro-climatic zone-II of Bihar for GW use at (2.65BCM)

\begin{tabular}{|l|}
\hline Crops \\
\hline Paddy \\
\hline Wheat \\
\hline Maize (rabi) \\
\hline Lentil \\
\hline Rapeseed \& mustard \\
\hline Sunflower \\
\hline Potato \\
\hline Cabbage \\
\hline Brinjal \\
\hline Cauliflower \\
\hline Okra \\
\hline Jute \\
\hline Chilli \\
\hline GCA \\
\hline Profit (00 crores) \\
\hline
\end{tabular}

\begin{tabular}{|c|c|c|c|c|}
\hline \multirow{2}{*}{$\begin{array}{l}\text { Existing } \\
\text { area (000 } \\
\text { ha) }\end{array}$} & \multicolumn{3}{|c|}{ Optimum area (000 ha) } & \multirow{2}{*}{$\begin{array}{l}\text { Direction of } \\
\text { change }\end{array}$} \\
\hline & $\begin{array}{l}\text { Market } \\
\text { price (MP) }\end{array}$ & $\begin{array}{l}\text { Economic } \\
\text { price (EP) }\end{array}$ & $\begin{array}{l}\text { Natural resource } \\
\text { valuation (NRV) }\end{array}$ & \\
\hline 681.67 & 750.00 & 750.00 & 750.00 & +++ \\
\hline 312.00 & 350.00 & 350.00 & 350.00 & +++ \\
\hline 174.12 & 200.00 & 200.00 & 200.00 & +++ \\
\hline 11.00 & 15.00 & 15.00 & 15.00 & +++ \\
\hline 19.70 & 20.00 & 20.00 & 20.00 & +++ \\
\hline 18.97 & 25.00 & 25.00 & 25.00 & +++ \\
\hline 34.28 & 40.00 & 40.00 & 40.00 & +++ \\
\hline 8.79 & 12.00 & 12.00 & 12.00 & +++ \\
\hline 12.57 & 15.00 & 15.00 & 15.00 & +++ \\
\hline 14.06 & 20.00 & 20.00 & 20.00 & +++ \\
\hline 13.24 & 20.00 & 20.00 & 20.00 & +++ \\
\hline 123.96 & 150.00 & 150.00 & 150.00 & +++ \\
\hline 0.68 & 1.00 & 1.00 & 1.00 & +++ \\
\hline \multirow[t]{2}{*}{1425.04} & 1618.00 & 1618.00 & 1618.00 & +++ \\
\hline & & & 21.17 & \\
\hline
\end{tabular}


Table.6 Gain due to optimal crop model over two different GW use scenario in Agro-climatic zone-II in Bihar

\begin{tabular}{|c|c|c|c|c|c|c|}
\hline Optimal scenario & $\begin{array}{l}\text { Change in } \\
\text { GCA\% }\end{array}$ & $\begin{array}{l}\text { Existing } \\
\text { revenue } \\
\text { (00 crores) }\end{array}$ & $\begin{array}{l}\text { Optimal } \\
\text { net returns } \\
(00 \text { crores) }\end{array}$ & $\begin{array}{l}\text { Change in farmer's } \\
\text { revenue } \\
\text { ( } 00 \text { crores) } \\
\text { (Optimal-Existing } \\
\text { MP) }\end{array}$ & $\begin{array}{l}\text { Gain to } \\
\text { society } \\
\text { (00 crores) }\end{array}$ & $\begin{array}{l}\text { Net Gain } \\
\text { (00 crores) }\end{array}$ \\
\hline \multicolumn{7}{|c|}{ Ground water use existing scenario ( 2.12 BCM) } \\
\hline Market price & 1.96 & 23.36 & 26.86 & 3.50 & 0 & 3.50 \\
\hline Economic price & 1.96 & 18.92 & 22.04 & -1.31 & 4.44 & 3.12 \\
\hline NRV & 1.96 & 17.58 & 20.87 & -2.49 & 3.10 & 0.61 \\
\hline \multicolumn{7}{|c|}{ Ground water use increased by $25 \%$ of existing GW use (2.65 BCM) } \\
\hline Market price & 13.54 & 23.36 & 27.71 & 4.36 & 0 & 4.36 \\
\hline Economic price & 13.54 & 18.92 & 22.64 & -0.71 & 4.44 & 3.72 \\
\hline NRV & 13.54 & 17.58 & 21.17 & -2.19 & 3.10 & 0.91 \\
\hline
\end{tabular}

Table.7 Optimum crop model for Agro-climatic zone-III of Bihar at existing groundwater use at $3.70 \mathrm{BCM}$

\begin{tabular}{|c|c|c|c|c|c|}
\hline \multirow[t]{2}{*}{ Crops } & \multirow{2}{*}{$\begin{array}{l}\text { Existing } \\
\text { area (000 } \\
\text { ha) }\end{array}$} & \multicolumn{3}{|c|}{ Optimum area (000 ha) } & \multirow{2}{*}{$\begin{array}{l}\text { Direction } \\
\text { of change }\end{array}$} \\
\hline & & $\begin{array}{l}\text { Market } \\
\text { price (MP) }\end{array}$ & $\begin{array}{l}\text { Economic } \\
\text { price (EP) }\end{array}$ & $\begin{array}{l}\text { Natural resource } \\
\text { valuation }(\mathrm{NRV})\end{array}$ & \\
\hline Paddy & 1154.00 & 1189.29 & 1189.29 & 1189.29 & +++ \\
\hline Wheat & 840.00 & 800.00 & 800.00 & 800.00 & --- \\
\hline Maize (kharif) & 33.31 & 35.00 & 35.00 & 35.00 & +++ \\
\hline Maize (rabi) & 55.19 & 50.00 & 50.00 & 50.00 & --- \\
\hline Ragi & 4.16 & 6.00 & 6.00 & 6.00 & +++ \\
\hline Arhar (RedGram) & 12.00 & 18.00 & 18.00 & 18.00 & +++ \\
\hline Kulthi (HorseGram) & 3.86 & 5.00 & 5.00 & 5.00 & +++ \\
\hline Gram & 58.64 & 70.00 & 70.00 & 70.00 & +++ \\
\hline Lentil & 116.84 & 150.00 & 150.00 & 150.00 & +++ \\
\hline Khesari (Lathyrus) & 68.49 & 70.00 & 70.00 & 70.00 & +++ \\
\hline Rapeseed \& mustard & 20.85 & 25.00 & 25.00 & 25.00 & +++ \\
\hline Linseed & 23.90 & 25.00 & 25.00 & 25.00 & +++ \\
\hline Potato & 40.67 & 55.00 & 55.00 & 55.00 & +++ \\
\hline Cabbage & 12.43 & 15.00 & 15.00 & 15.00 & +++ \\
\hline Brinjal & 15.30 & 20.00 & 20.00 & 20.00 & +++ \\
\hline Cauliflower & 19.88 & 25.00 & 25.00 & 25.00 & +++ \\
\hline Okra (Bhindi) & 24.55 & 26.00 & 26.00 & 26.00 & +++ \\
\hline Tomato & 21.47 & 25.00 & 25.00 & 25.00 & +++ \\
\hline Onion & 22.33 & 26.00 & 26.00 & 26.00 & +++ \\
\hline Chilli & 1.00 & 1.50 & 1.50 & 1.50 & +++ \\
\hline GCA & 2548.86 & 2636.79 & 2636.79 & 2636.79 & +++ \\
\hline Profit (00 crores) & & & & 29.15 & \\
\hline
\end{tabular}


Table.8 Optimum crop model for Agro-climatic zone-III of Bihar by increasing 25\% of existing GW use (4.63 BCM)

\begin{tabular}{|l|l|l|l|l|l|}
\hline Crops & $\begin{array}{l}\text { Existing } \\
\text { area (000 } \\
\text { ha) }\end{array}$ & $\begin{array}{l}\text { Optimum Area (000 ha) } \\
\text { Market }\end{array}$ & $\begin{array}{l}\text { Economic } \\
\text { price (EP) }\end{array}$ & $\begin{array}{l}\text { Natural resource } \\
\text { valuation(NRV) }\end{array}$ & $\begin{array}{l}\text { Direction } \\
\text { of change }\end{array}$ \\
\hline Paddy & 1154.00 & 1500.00 & 1500.00 & 1500.00 & +++ \\
\hline Wheat & 840.00 & 1000.00 & 1000.00 & 1000.00 & +++ \\
\hline Maize (kharif) & 33.31 & 35.00 & 35.00 & 35.00 & +++ \\
\hline Maize (rabi) & 55.19 & 55.00 & 55.00 & 55.00 & +++ \\
\hline Ragi & 4.16 & 6.00 & 6.00 & 6.00 & +++ \\
\hline Arhar (RedGram) & 12.00 & 18.00 & 18.00 & 18.00 & +++ \\
\hline Kulthi (HorseGram) & 3.86 & 5.00 & 5.00 & 5.00 & +++ \\
\hline Gram & 58.64 & 70.00 & 70.00 & 70.00 & +++ \\
\hline Lentil & 116.84 & 150.00 & 150.00 & 150.00 & +++ \\
\hline Khesari (Lathyrus) & 68.49 & 70.00 & 70.00 & 70.00 & +++ \\
\hline Rapeseed \& & 20.85 & 25.00 & 25.00 & 25.00 & +++ \\
\hline mustard & & & & & +++ \\
\hline Linseed & 23.90 & 25.00 & 25.00 & 25.00 & +++ \\
\hline Potato & 40.67 & 55.00 & 55.00 & 55.00 & +++ \\
\hline Cabbage & 12.43 & 15.00 & 15.00 & 15.00 & +++ \\
\hline Brinjal & 15.30 & 20.00 & 20.00 & 20.00 & +++ \\
\hline Cauliflower & 19.88 & 25.00 & 25.00 & 25.00 & +++ \\
\hline Okra (Bhindi) & 24.55 & 26.00 & 26.00 & 26.00 & +++ \\
\hline Tomato & 21.47 & 25.00 & 25.00 & 25.00 & +++ \\
\hline Onion & 22.33 & 26.00 & 26.00 & 26.00 & +++ \\
\hline Chilli & 1.00 & 1.50 & 1.50 & 1.50 & ++ \\
\hline GCA & 2548.86 & 3152.50 & 3152.50 & 3152.50 & $\mathbf{+}$ \\
\hline Profit (00 crores) & & & & 32.51 & + \\
\hline
\end{tabular}

Table.9 Gain due to optimal crop model over existing scenario of Agro-Climatic zone-III in Bihar

\begin{tabular}{|c|c|c|c|c|c|c|}
\hline $\begin{array}{l}\text { Optimal } \\
\text { scenario }\end{array}$ & $\begin{array}{l}\text { Change } \\
\text { in } \\
\text { GCA \% }\end{array}$ & $\begin{array}{l}\text { Existing } \\
\text { revenue } \\
\text { (00 } \\
\text { crores) }\end{array}$ & $\begin{array}{l}\text { Optimal } \\
\text { net } \\
\text { returns } \\
\text { ( } 00 \\
\text { crores) }\end{array}$ & $\begin{array}{l}\text { Change in farmer's } \\
\text { revenue } \\
\text { (00 crores) } \\
\text { (Optimal-Existing } \\
\text { MP) }\end{array}$ & $\begin{array}{l}\text { Gain to } \\
\text { society } \\
\text { (00 } \\
\text { crores) }\end{array}$ & $\begin{array}{l}\text { Net gain } \\
\text { (00 } \\
\text { crores) }\end{array}$ \\
\hline \multicolumn{7}{|c|}{ Ground water use existing scenario (3.70 BCM) } \\
\hline Market price & 3.45 & 37.00 & 40.27 & 3.27 & 0 & 3.27 \\
\hline Economic price & 3.45 & 27.97 & 31.00 & -6.00 & 9.03 & 3.03 \\
\hline NRV & 3.45 & 26.07 & 29.15 & -7.84 & 7.13 & -0.72 \\
\hline \multicolumn{7}{|c|}{ Groundwater use increased by $25 \%$ of existing GW (4.63 BCM) } \\
\hline Market price & 23.68 & 37.00 & 46.14 & 9.15 & 0 & 9.15 \\
\hline Economic price & 23.68 & 27.97 & 34.97 & -2.03 & 9.03 & 6.99 \\
\hline NRV & 23.68 & 26.07 & 32.51 & -4.49 & 7.13 & 2.64 \\
\hline
\end{tabular}


Perusal of the Table 4 (existing GW use at $2.12 \mathrm{BCM}$ ) revealed that the positive change in optimal area allocation was found for almost all crops except paddy which showed decline in its area as compared to the existing area in zone-II Further, it was observed increase in optimal GCA as compared to the existing GCA in this region i.e. as much as 1452.90 thousand hectares from existing 1425.04 thousand hectares.

When the GW use was increased to 2.65 BCM, the estimation of optimal model showed positive direction of changes in all the crops in study under zone-II. It also revealed the change in optimal GCA 1618.00 thousand hectares as compared to the existing only 1425.04 thousand hectares.

On the basis of the above two different GW use scenarios the gain was also calculated and presented in Table 6.

The table indicated that in the first condition, the optimal GCA increased by $1.96 \%$ and change in farmers' revenue was evaluated positive (3.50 hundred crores) at market price but it was calculated negative as -1.31 \& 2.49 hundred crores at other two business scenarios i.e. economic price and NRV price, respectively. The estimated optimal profit at existing GW use scenario was 20.87 hundred crores at NRV business prices. Further, the net gains from optimal model were estimated to $3.50,3.12$ and 0.61 hundred crores at all alternative business prices, using existing $\mathrm{GW}$ scenario.

But, on the basis of the next condition i.e. 2.65 BCM GW use, the change in optimal GCA was computed by $11.53 \%$ and changes in farmer's gain was calculated to be positive i.e. 4.36 hundred crores on market price condition, whereas for rest two other prices conditions, the gain was found to be negative i.e. 0.71 and -2.19 hundred crores at their respective economic and NRV prices. It was further revealed that the net gains were accounted for positive in all business scenarios considered in the optimal model in the study.

\section{Optimal crop model for Agro-climatic zone-III}

Agro-climatic zone-III is considered as water scarce region of the state, however it is agriculturally more developed than other two zones of the state. Optimal crop model for the zone was also worked out on the basis of two groundwater use conditions i.e first at existing $\mathrm{GW}$ use (3.70 BCM) and second at (4.63 BCM) GW use and are presented in Table 7 , Table 8 and Table 9.

Perusal of the Table 7 indicated that at existing GW use (3.70 BCM), it was figured out that paddy, kharif maize, ragi, arhar, kulthi, gram, lentil khesari, rapeseed \& mustard, linseed, potato, cabbage, brinjal, cauliflower, bhindi, tomato, onion and chilli showed positive direction of change in its optimal area allocation and two crops such as wheat and rabi maize included in the model for this zone showed retarded change in optimal area allocation. Consequently, optimal GCA also depicted positive direction of change, thus the GCA escalated from existing area of 2548.86 thousand hectares to optimum area being 2636.79 thousand hectares.

When the groundwater use was enhanced up to $4.63 \mathrm{BCM}$, all the crops consisting in the model came out with the positive direction of change in optimal area allocation and thus, the positive change was also accounted for in case of optimal GCA i.e. it would scaled up from 2548.86 thousand hectares to 3152.50 thousand hectares in Agro-climatic zone-III. Consequently the level of profit i.e. 32.51 hundred crores would be obtained from this optimal model. 
Net gain due to optimal area allocation for zone-III is presented in Table 9. A critical view of the table pointed out that at existing GW use at $3.70 \mathrm{BCM}$, optimal net returns were estimated 40.27, 31.00 and 29.15 hundred crores at three different prices (MP, EP and NRV, respectively), but change in farmer's revenue was found positive (3.27 hundred crores) at market price only. Further the net gains were accounted for $3.27 \& 3.03$ hundred crores at market price and economic price but it (net gain) was found negative $(-0.72$ hundred crores) at NRV price. Further, it was also observed an increase of $3.45 \%$ in optimal GCA as compared to existing GCA of the zone-III.

When GW use was increased to $4.63 \mathrm{BCM}$, the optimal crop model exhibited change in optimal GCA by $23.68 \%$. Change in farmers' revenue was found positive only in case of market price but gain to the society at two prices EP and NRV were calculated 9.03 and 7.13 hundred crores, respectively and the final net gain to cultivators were estimated 9.15, 6.99 and 2.64 hundred crores at MP, EP and NRV, respectively under this GW use scenario.

In conclusion, analysis of optimum crop model for different agro-climatic zones of Bihar revealed that from the point of view of optimum area allocation for crops grown in the zone-I with existing ground water use at $4.50 \mathrm{BCM}$, that almost all crops included in the model showed positive direction of changes in optimal area allocation in all the three prices scenario i.e. MP, EP and NRV in this zone. The net gain to the cultivator was obtained positive at all the three prices i.e. 9.18 hundred crores at MP, 7.70 hundred crores at EP and 2.98 hundred crores at NRV prices. The optimal crop models for zoneII were also estimated using two different groundwater use scenarios i.e. one at $2.12 \mathrm{BCM}$ existing GW use and another groundwater use increased to $2.65 \mathrm{BCM}$ (increased by $25 \%$ of existing GW use). In the first condition, the optimal GCA increased by $1.96 \%$ and change in farmers' revenue was evaluated positive (3.50 hundred crores) at market price but it was calculated negative as $-1.31 \&-2.49$ hundred crores at other two business scenarios i.e. economic price and NRV price, respectively. The estimated optimal profit at existing GW use scenario was 20.87 hundred crores at NRV business prices. Further, the net gains from optimal model were estimated to $3.50,3.12$ and 0.61 hundred crores at all alternative business prices, using existing GW scenario. But, on the basis of the next condition i.e. 2.65 BCM GW use, the change in optimal GCA was computed by $11.53 \%$ and changes in farmer's gain was calculated to be positive i.e. 4.36 hundred crores on market price condition, whereas for rest two other prices conditions, the gain was found to be negative i.e. -0.71 and -2.19 hundred crores at their respective economic and NRV prices. It was further revealed that the net gains were accounted for positive in all business scenarios considered in the optimal model in the study.

Agro-climatic zone-III is considered as water scarce region of the state however it is agriculturally more developed than other two zones of the state. Optimal crop model for the zone was also worked out on the basis of two groundwater use conditions i.e. first at existing GW use (3.70 BCM) and second at (4.63 BCM) GW use. The results indicated that at existing GW use (3.70 BCM), it was figured out that optimal GCA depicted positive direction of change and the GCA escalated from existing area of 2548.86 thousand hectares to optimum area being 2636.79 thousand hectares. When GW use was increased to $4.63 \mathrm{BCM}$, the optimal crop model exhibited change in optimal GCA by $23.68 \%$. Change in farmers' revenue was found positive only in case of market price but gain to the society at two prices EP and NRV were calculated 9.03 and 7.13 hundred crores, respectively and the final net gain to cultivators were estimated 9.15, 6.99 and 2.64 hundred crores on MP, EP and NRV, respectively under this GW use scenario.

Hence, all crop models as discussed above may be used for the optimization of income of the farming community provided that the groundwater development is created/ enhanced as well as means of irrigation made available by 
the government to the cultivators of the state. Renewal sources of energy may be popularized for use with a view to reduce the expenditure burden on usual diesel irrigation and protecting the society from ill effect of air pollution generated through the use of diesel. Infrastructural development with regard to uninterrupted supply of electricity and solar energy may be expanded for better adoption and acceptability of the optimal models among the farming community in order to enhance income and raising standard of living conditions of poor peasants of the state.

\section{Acknowledgement}

The paper is based on Report of ICAR-Social Science Network Project "Regional Crop Planning for Improving Resource Use Efficiency and Sustainability funded by NIAP, New Delhi. Authors are thankful to Dr. Rajni Jain and Dr. S.K. Srivastava, NIAP for their technical help.

\section{References}

Dahiphale, Pravin, Singh P.K., Kothari Mahesh and Gharde Kishore 2015. Optimal Cropping Pattern for Jaisamand command of Udaipur district in Rajasthan, India. Research Journal of Recent Sciences Vol. 4) ISC-2014): 1-7.

GoI (Government of India) 2011. Central Ground Water Board, Ministry of Water Resources, New Delhi, available at: http://cgwb.gov.in/

IIPR (Indian Institute of Pulses Research) 2003. Pulses in new perspective, In
Proceedings of the National Symposium on Crop Diversification and Natural Resource Management, Kanpur. pp. 20 -22 .

Peoples, M. B., Ladha, J. K. and Herridge, D. F. 1995. Enhancing legume $\mathrm{N}_{2}$ fixation through plant and soil management. Developments in Plant and Soil Sciences, 174: 83-101.

Raghava Rani Y. and Tirupathi Rao P. 2012. Multi-objective Crop Planning for Optimal Benefits IJERA Vol. 2, Issue 5 pp.279-287.

Raju, S.S., Ramesh Chand, S. K. Srivastava, Amrit Pal Kaur, Jaspal Singh, Rajni Jain, Kingsly Immaneulraj and Parminder Kaur 2015. Comparing Performance of Various Crops in Punjab Based on Market and Economic Prices and Natural Resource Accounting, Agricultural Economics Research Review, 28 (Conference issue).

Singh, K.M., Dixitand R.S and Singh, D.K. 1990. District level agricultural planning for Almora district, Uttar Pradesh-A multi-level, multi-objective programming approach. Economic Affairs, 35 (1): 48-56.

Singh, R.K.P., Singh, K.M.and Kumar,. Abhay 2015. Agricultural Development in Bihar: Some Empirical Evidences. Agricultural Situation in India, Vol.LXX (12): 5-13

Sinha DK, Ahmad N and Singh KM. 2016. Shrinking Net Sown Area: An Analysis of Changing Land Use Pattern in Bihar. Journal ofAgriSearch 3(4): 238-243

\section{How to cite this article:}

Nasim Ahmad, D.K. Sinha and Singh, K.M. 2018. Optimal Use of Agricultural Land and Water Resources through Reconfiguring Crop Plan for different Agro-Climatic Zones of Bihar (India). Int.J.Curr.Microbiol.App.Sci. 7(01): 3397-3409. doi: https://doi.org/10.20546/ijcmas.2018.701.402 